\title{
EFFECTS OF DIURNAL AND NOCTURNAL STRENUOUS EXERCISE ON SERUM MELATONIN LEVELS
}

\author{
EFEITOS DO EXERCÍCIO EXTENUANTEDIURNO ENOTURNO SOBRE OS NÍVEIS SÉRICOS DEMELATONINA
}

EFECTOS DEL EJERCICIO EXTENUANTE DIURNO Y NOCTURNO EN LOS NIVELES SÉRICOS DE LA MELATONINA

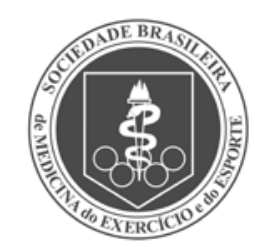

Original Article ARTIGO ORIGINAL Artículo Original

\begin{abstract}
Mehmet Kilic ${ }^{1}$
(Educador Físico)

Bilal Demirhan ${ }^{2}$

(Educador Físico)

Suleyman Patlar ${ }^{1}$

(Educador Físico)

Abdulkerim Kasim Baltaci ${ }^{3}$

(Fisiologista)

Rasim Mogulkoc ${ }^{3}$ (Fisiologista)

1. Selcuk University, High School of Physical Education and Sport, Konya, Turkey.

2. Samsun Ondokuz Mayıs University, Yasar Dogu Faculty of Sport Sciences, Samsun, Turkey.

3. Selcuk University, Medical School, Department of Physiology, Konya, Turkey.
\end{abstract}

\section{Correspondência:}

Suleyman Patlar. High School of Physical Education and Sport,

Selcuk University, Campus, 42031 Selçuklu, Konya, Turkey. s.patlar@yahoo.com.tr

\begin{abstract}
Introduction: There are reports of a possible relationship between melatonin, a hormone secreted by the pineal gland, and exercise. Objective: The present study aims to investigate how diurnal and nocturnal strenuous exercise affects melatonin levels. Methods: The study enrolled 10 healthy sedentary males who did not actively exercise. The subjects had a mean age of $22.20 \pm 0.24$ years, a mean height of $174.60 \pm 2.33 \mathrm{~cm}$, and a mean weight of $69.70 \pm 2.42$ $\mathrm{kg}$. Two blood samples were collected from the subjects, one at rest, at 10:00 am, and the other immediately after strenuous exercise. Likewise, blood samples were taken from the same group of subjects after 48 hours: at 24:00 hours at rest and immediately after strenuous exercise. Samples were analyzed using the ELISA method to determine the serum melatonin levels (pg/ml). Results: By comparing the values at rest and after exercise, it was found that serum melatonin values remained unchanged with exercise. Serum melatonin values at rest or post-exercise measured at night were higher when compared with those measured during the day $(p<0.05)$. Conclusions: Higher levels of melatonin found in the study appear to result from the increased release of melatonin at night, and not from exercise. The results of this study indicate that strenuous exercise carried out day or night, did not significantly influence serum melatonin levels.
\end{abstract}

Keywords: exercise; pineal gland; melatonin; fatigue.

\section{RESUMO}

Introdução: Hárelatos de uma possivel relação entre a melatonina, hormônio secretado pela glândula pineal, eexercício. Objetivo: O presente estudo tem como objetivo investigar como o exercício extenuante diurno e noturno afeta os níveis de melatonina. Métodos: O estudo inscreveu 10 homens sedentários saudáveis que não se exercitavam ativamente. Os

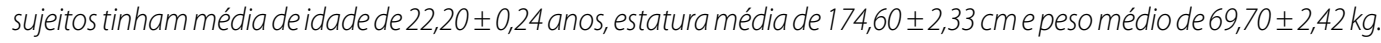
Duas amostras de sangue foram coletadas dos sujeitos, uma em repouso, às 10 h00 da manhã e a outra imediatamente após exercício extenuante. Da mesma forma, foram coletadas amostras de sangue do mesmo grupo de sujeitos depois de 48 horas: às 24 h00 em repouso e imediatamente após exercício extenuante. As amostras foram analisadas pelo método ELISA para determinar os nivivis séricos de melatonina (pg/ml). Resultados: Ao serem comparados os valores de repouso e depois do exercício, verificou-se que os valores séricos de melatonina permaneceram inalterados após exercício. Os valores séricos de melatonina em repouso e pós-exercício, medidos à noite foram mais elevados em comparação com os valores medidos durante o dia $(p<0,05)$. Conclusões: Os níveis elevados de melatonina encontrados no estudo parecem resultar do aumento da liberação de melatonina à noite, e não do exercício. Os resultados deste estudo indicam que o exercício extenuante realizado durante o dia ou à noite, não influenciou significativamente os níveis séricos de melatonina.

Descritores: exercício; glândula pineal; melatonina; fadiga.

\section{RESUMEN}

Introducción: Hay reportes de una posible relación entrela melatonina, una hormona secretada por la glándula pineal, y el ejercicio. Objetivo: Este estudio tiene como objetivo investigar cómo el ejercicio extenuante diurno y nocturno afecta a los niveles de melatonina. Métodos: En el estudio participaron 10 hombres sanos sedentarios que no hacían ejercicio de forma activa. Los sujetos tenían una edad promedio de 22,20 $\pm 0,24$ años, altura promedio de 174,60 2,33 cm, y peso promedio de 69,70 $\pm 2,42 \mathrm{~kg}$. Dos muestras de sangre se obtuvieron de los sujetos, una en reposo, a las 10:00 horas de la mañana la otra inmediatamente después del ejercicio vigoroso. Igualmente, las muestras de sangre se recogieron del mismo grupo de sujetos después de 48 horas: a las 24:00 horas en reposo e inmediatamente después del ejercicio extenuante. Las muestras se analizaron usando el método ELISA para determinar los niveles de melatonina en suero (pg/m/). Resultados: Mediante la comparación de los valores en reposo y después del ejercicio, se encontró que los valores séricos de melatonina se mantuvieron sin cambios después del ejercicio. Ambos valores de melatonina en reposo y después del ejercicio, medidos por la noche fueron más altos en comparación con los medidos durante el día $(p<0,05)$. Conclusiones: Los altos niveles de melatonina encontrados en el estudio parecen ser el resultado del aumento de la liberación de melatonina en la noche, y no del ejercicio. Los resultados de este estudio indican que el ejercicio extenuante realizado durante el día o por la noche, no afectó significativamente los niveles de melatonina en suero.

Descriptores: ejercicio; glándula pineal; melatonina; fatiga. 


\section{INTRODUCTION}

There has been mention of a possible relation between the melatonin hormone secreted by pineal gland and exercise'. A growing body of evidence suggests that exercise may have both acute and long-lasting effects on melatonin secretion?2. In a study where the effects of melatonin on carbohydrate and lipid metabolism were examined, the experimental animals were run to exhaustion at $24 \mathrm{~m} / \mathrm{min}$ and a $12 \%$ slope and it was observed that exercise caused significant hypoglycemia, elevated plasma lactate and beta-hydroxybutirate levels, and led to a significant decrease in glycogen in the muscles and liver. The same study showed that muscle and liver glycogen content was significantly higher, while plasma and liver lactate, as well as plasma beta-hydroxybutirate levels were significantly lower in melatonin-treated exercised rats. These data were interpreted as an indication of melatonin's preservation of glycogen stores through the changes in carbohydrate and lipid utilization in exercised rats ${ }^{3}$.

It was noted that elevated plasma lactate levels following pinealectomy could cause muscle tiredness, producing a negative effect on performance, whereas melatonin administration could delay tiredness and improve physical performance ${ }^{4}$. Another remarkable example of the relation between melatonin and exercise is the report that melatonin administration restored the reduced liver glycogen levels in rats subjected to an acute swimming exercise $e^{5}$. The fact that melatonin preserves muscle and liver glycogen in exercised rats suggests that melatonin may prolong exercise duration in humans ${ }^{6}$.

Furthermore, melatonin supplementation before strenuous exercise was reported to reduce muscle injury by mitigating the effects of oxidative stress and inflammation?. It was established in a study exploring the effect of nocturnal exercise on melatonin in rats that levels of melatonin in both the pineal gland and plasma dropped in rats which were exposed to light during nocturnal exercise ${ }^{8}$. Consequently, many researchers suggest an inevitable relationship between melatonin and exercise. In their study with children, Perez Nevero et al. ${ }^{9}$ reported that physical activity led to a significant increase in melatonin levels.

Similarly, Carr et al. ${ }^{10}$ showed a significant increase in the post-exercise plasma melatonin levels in females. Monteleone et al. ${ }^{11}$ stated that plasma melatonin levels might rise 5 hours after physical activity. On the contrary, Skrinar et al. ${ }^{12}$ reported in their study that strenuous exercise might cause a decrease, rather than an increase, in melatonin levels. The results of these studies indicate that there is no consensus on the relation between melatonin and exercise. The purpose of the present study is to examine how daytime and night exercise to exhaustion affects serum melatonin levels.

\section{METHODS}

This study registered 10 healthy and sedentary males not actively engaged in any branch of sports. The mean age of the subjects was $22,20 \pm 0,24$ years, mean height was $174,60 \pm 2,33 \mathrm{~cm}$, and mean weight was $69,70 \pm 2,42 \mathrm{~kg}$. The study protocol was approved 08.22.2011 date and 2011/009 numbered with ethics committee decision by the Ethics Committee of Selcuk University School of Physical Education and Sports. The clarified consent form was signed that Including risks and discomforts could be encountered related work detailed information by each of the subjects before study.

Blood samples of $2,5 \mathrm{ml}$ were collected from the forearm vena of the subjects at 10.00 in the morning during rest and immediately after exercise until exhaustion. Blood samples were collected from the same group of subjects for the third time at 24.00 at night before exhaustion exercise and for the fourth time immediately after exhaustion exercise. The samples were centrifuged at 3000 rotations for 10 minutes to separate the serum, which was then stored at $-80^{\circ} \mathrm{C}$ until the time of melatonin analysis.

Serum melatonin levels were determined as pg/ml using ELISA test kits
(USCN Life Science Inc. P.R. China, Lot No: L110707148) and Biotek ELX800 and ELX50 plate reader and washer devices.

Exhaustion exercises were performed once during daytime and once at night as acute exercises until exhaustion. Exhaustion exercise was carried out according to the Bruce protocol (Cosmed T150 treadmill), which is the most common clinical exercise test. During the exercises the slope and speed of the treadmill was increased in 3-minute periods and the exercise was conducted up to the point where the subject could no longer continue.

\section{Statistical evaluations}

SPSS (Statistical Package for the Social Sciences) 21.0 software package (SPSS, Inc., Chicago, L, USA) was used for the statistical evaluation of data.

Arithmetic means and standard deviations of all parameters were calculated. Repeated Measures Analysis of Variance was used to detect the differences in the measurements conducted at different times and the Least Significant Difference (LSD) test was employed to determine the period from which the difference originated. Differences for which $p<0,05$ were accepted significant.

\section{RESULTS}

There was no statistically significant difference between melatonin levels of subjects measured at rest and after exercise during daytime (Table 1, Figure 1). Similarly, no difference was found between the resting and post-exercise serum melatonin levels of subjects measured at night (Table 1, Figure 1).

When both nocturnal and diurnal serum melatonin levels found during rest and after exercise were considered, the highest serum melatonin levels were seen in the night time measurements (both during rest and after exercise) (Table 1, Figure 1, p<0,05).

\section{DISCUSSION}

In this study, no statistically significant difference was found between serum melatonin levels measured at rest and after exercise during daytime. Buxton et al. ${ }^{2}$ stated that the major factors that determined the exercise-induced changes in melatonin levels were the type, intensity and duration of exercise. It was reported that exercise significantly elevated plasma melatonin concentrations in 7 young women who attended an 8-week aerobic exercise course ${ }^{13}$. In another study which included

Table 1. Serum melatonin levels of the subjects $(\mathrm{pg} / \mathrm{ml})$

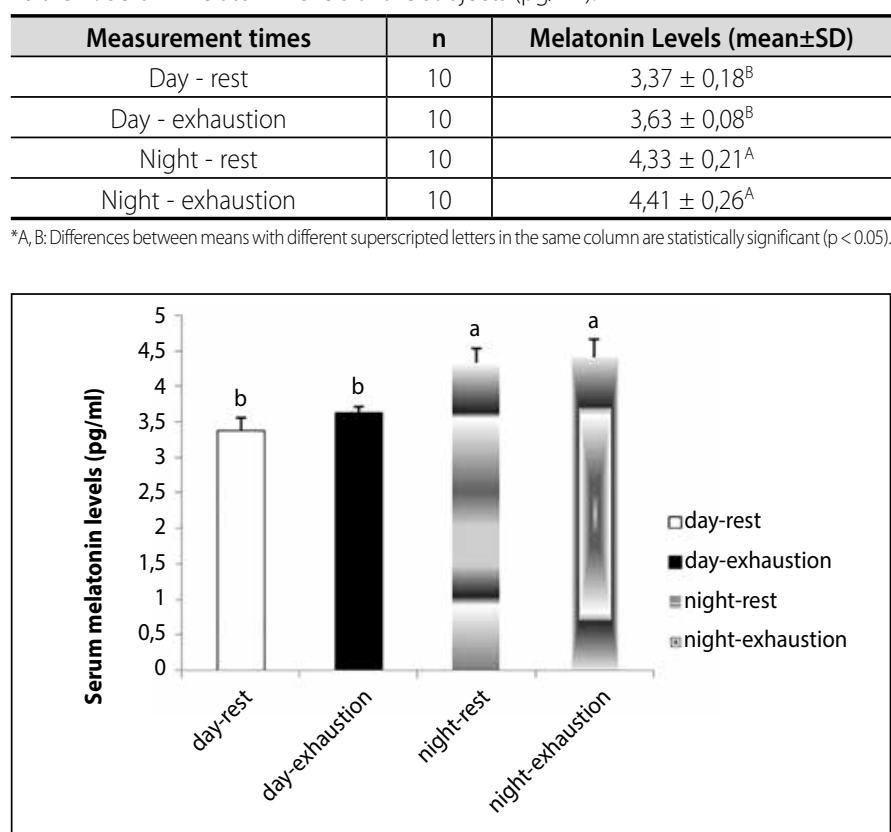

Figure 1. Serum melatonin levels of the subjects (pg/ml). 
healthy adult males, it was noted that the melatonin levels which increased immediately after physical activity were restored to pre-exercise resting levels an hour after the activity ${ }^{13}$. Perez Nevero et al. ${ }^{9}$ demonstrated in their study including children that physical activity led to a significant increase in melatonin levels. In the same vein, Carr et al. ${ }^{10}$ reported a significant post-exercise rise in plasma melatonin levels in females. Monteleone et al. ${ }^{11}$ pointed out that plasma melatonin levels might drop five hours after physical activity. However, Skrinar et al. ${ }^{12}$ stated in their study that strenuous exercise might bring about a decrease, rather than an increase, in melatonin levels. The results of these studies are inconsistent with the post-exercise serum melatonin levels we measured during the day. However, the report that physical activity did not cause any change in the melatonin levels of female athletes ${ }^{14}$ is consistent with the melatonin levels we found both at rest and after exercise during the day. Similarly, in a study conducted on 7 male volunteers, no significant change was found in the melatonin levels measured in blood samples collected in four rounds: before exercise, 30 seconds after exercise, and 15 and 30 minutes after exercise ${ }^{15}$. This is a significant report lending support to the results we obtained with daytime exercise.

In a study by Buxton et al. ${ }^{16} 8$ healthy individuals were subjected to 3 hours of moderate exercise and 1 hour of high-intensity exercise to find out the effects of the duration and intensity of nocturnal physical activity on human circadian rhythms. It was concluded that nighttime physical activity impaired the human circadian rhythm. In a clinical study of normal adult black males, melatonin levels before, immediately after and 1 hour following physical exercise were examined and it was found that melatonin levels were restored to pre-exercise levels one hour after physical activity ${ }^{13}$. It was established in the same study that the subjects who exercised in a room with dimmed lighting (54 lux) had higher plasma melatonin levels than those who exercised in a lighted environment (320 lux) and a significant and positive correlation was found between post-exercise melatonin levels, and body mass, age, and pulse rate of the former ${ }^{13}$. Exercise acutely alters melatonin levels and changes the levels of melatonin secreted at night after 12-24 hours ${ }^{17}$. Both acute and delayed effects arise depending on the timing of exercise ${ }^{2}$. In a study exploring the effects of nighttime exercise on melatonin in rats, the animals were divided into two groups. The animals in the first group swam in the dark at 00.30, while those in the second group swam at the same hour but by being exposed to light for
15 and 30 minutes. It was reported in the concerned study that melatonin content of the pineal gland dropped rapidly in swimming exercise, while the activity of $\mathrm{N}$-acetyltransferase (NAT), a critical enzyme in melatonin synthesis, remained unchanged. Conversely, the rats which were exposed to light were found to have lower levels of melatonin both in the pineal gland and the plasma ${ }^{8}$. The results of Yaga et al. ${ }^{8}$ are contradictory with the serum melatonin levels we obtained during rest and after exercise at nighttime, as we did not find any significant difference between serum melatonin levels measured during rest and after exercise at nighttime and the measurements conducted during the day. The reason for this lack of difference is probably the fact that, irrespective of its severity and intensity, daytime exercise does not have any consistent acute effect on melatonin secretion ${ }^{2}$

An overall assessment of serum melatonin levels measured at rest and immediately after exercise to exhaustion both during the day and at night revealed that the highest serum melatonin levels were found at night (both during rest and immediately after exercise). That nocturnal serum melatonin levels were higher than diurnal levels both during rest and after exercise in our study should be considered a result that is not dependent on exercise. This is because melatonin synthesis and secretion is in a close relation with the amount of light ${ }^{18}$. Blood melatonin levels are characterized by being at the maximum at night and at the minimum during daytime. Melatonin concentrations in the systemic blood flow, pineal gland, cerebrospinal fluid, urine, and cell measured at night go up as high as ten times the levels measured during the day ${ }^{19}$. As soon as darkness falls, melatonin levels begin to increase. They reach a peak after midnight (02.00-04.00) and then gradually fall ${ }^{20}$. High melatonin levels we found both during rest and after exercise in the nighttime measurements in our study result from the nocturnal increase in melatonin secretion, as suggested by the researchers cited above.

\section{CONCLUSION}

The results of our study indicate that exhaustion exercises both during the day and at night do not have any significant effect on serum melatonin levels.

All authors have declared there is not any potential conflict of interests concerning this article.

\begin{abstract}
AUTHORS' CONTRIBUTIONS: Each author contributed individually and significantly to the development of the manuscript. MK (0000-0002-8917-9048)* and BD (0000$0002-3063-9863)^{*}$ was responsible for data collection, data analysis and interpretation, and the writing of the draft. SP (0000-0003-3817-3575)* helped with statistical analysis and writing of the manuscript. RM (0000-0001-6155-6780)* helped in data analysis and interpretation. AKB (0000-0003-2461-1212)* designed the study and supervised the data collection, analysis, and supervised the writing of the manuscript. All authors read and approved the final manuscript. *ORCID (Open Researcher and Contributor ID).
\end{abstract}

\section{REFERENCES}

1. Cagnacci A, Arangino S, Angiolucci M, Maschio E, Melis GB. Influences of melatonin administration on the circulation of women. Am J Physiol 1998;274:335-8.

2. Buxton OM, L'Hermite-Baleriaux M, Hirschfeld U, Cauter E. Acute and delayed effects of exercise on human melatonin secretion, J Biol Rhythms 1997b;12:568-74.

3. Mazepa RC, Cuevas MJ, Collado PS, Gonzales-Gallego J. Melatonin increases muscle and liver glycogen content in nonexercised and exercised rats. Life Sci 2000;66:153-60.

4. Baltaci AK, Cumraligil B, Kilic M, Kaya O. Effect of acute swimming exercise on lactate levels and its relation with zinc in pinealectomised rats. Cell Bıchemistry And Function 200725:597-601.

5. Bicer M, Akil M, Avunduk MC, Kilic M, Mogulkoc R, Baltaci AK. Interactive effects of melatonin, exercise and diabetes on liver glycogen levels. Endokrynologia Polska 2011;62:252-55.

6. Atkinson G, Drust B, Reilly T, Waterhouse J. The relevance of melatonin to sports medicine and science. Sports Med 2003;33:809-31

7. Ochoa JJ, Díaz-Castro J, Kajarabille N, García C, Guisado IM, De Teresa C, et al. Melatonin supplementation ameliorates oxidative stress and inflammatory signaling induced by strenuous exercise in adult human males. J Pineal Res 2011; 51:373-80.

8. Yaga K, Tan DX, Reiter RJ, Manchester LC, Hattori A. Unusual reponses of noctural pineal melatonin synthesis and secretion to swimming: attempts to define mechanisms.J Pineal Research 1993;14:98-103.

9. Perez Nevero JL, Jaraba Caballero S, Ibarra de la Rosa I, Jaraba Caballero MP, Guillén del Castillo M, Montilla López $\mathrm{P}$, et al. Effects of competitive physical exercise on neuroendocrine response and interleukin-6 liberation in children. An Esp Pediatr 1999; 51: 267-72.

10. Carr DB, Reppert SM, Bullen B, Skrinar G, Beitins I, Arnold M, et al. Plasma melatonin increases during exercise in women. 1981;53(1):224-5.
11. Monteleone P, Maj M, Franza F, Fusco R, Kemali D. The human pineal gland responds to stress-induced sympathetic activation in the second half of the dark phase preliminary evidence. J Neural Transm Gen Sect 1993;92:25-32.

12. Skrinar GS, Bullen BA, Reppert SM, Peachey SE, Turnbull BA, MCArthur JW. Melatonin response to exercise training in women. J Pineal Res 1989;7:185-94

13. Theron JJ, Oosthuizen JM \& Rautenbach MM. Effect of physical exercise on plasma melatonin leves in normal volunteers. S Afr Med J 1984;66:838-41.

14. Ronkainen $\mathrm{H}$, Vakkuri O \& Kauppila A. Effects of physical exercise on the serum concentration of melatonin in female runners. Acta Obstet Gynecol Scand 1986; 65: 827-29.

15. Elias AN, Wilson AF, Pandian MR, Rojas FJ, Kayaleh R, Stone SC, et al. Melatonin and gonadotropin secretion after acute exercise in physically active males. Eur J Appl Physiol 1993;66:357-61.

16. Buxton OM, Frank SA, L'Hermite-Baleriaux M, Leproult R, Turek FW, Van Cauter E. Roles of intensity and duration of nocturnal exercise in causing phase delays of human circadian rhythms. Am J Physiol 1997a;273:536-42.

17. Van Cauter E, Sturis J, Byrne MM, Blackman JD, Scherberg NH, Leproult R, et al. Preliminary studies on the immediate phase-shifting effects of light and exercise on the human circadian clock. J Biol Rhythms 1993;8:99-108

18. Bediz CS, Baltaci AK\& Mogulkoc R. Both zinc deficiency and supplementation affect plasma melatonin levels in rats. Acta Physiol Hung, 2003;90:335-339.

19. Anisimov VN. Effects of exogenous melatonin--a review. Toxicol Pathol 2003;31:589-603.

20. Beyer CE, Steketee JD \& Saphier D. Antioxidant properties of melatonin--an emerging mystery Biochem Pharmacol, 1998; 56: 1265-1272. 